\title{
PENGARUH KOMPETENSI AUDITOR, KOMITMEN PROFESIONAL DAN ETIKA PROFESI TERHADAP PERILAKU DISFUNGSIONAL AUDITOR
}

\author{
Rahman Pura \\ STIEM Bongaya Makassar \\ Email: sahman_aslam@yahoo.comatau rahmanpura@stiem-bongaya.ac.id
}

\begin{abstract}
The research problem is related to the dysfunctional behavior of auditors in performing audit tasks. The research objective was to measure and analyze the influence of auditor competence, professional commitment and professional ethics on the dysfunctional behavior of auditors at the Representative Audit Board of South Sulawesi Province. The data collection method used a questionnaire technique with a total of 54 auditors as respondents. Data analysis using multiple regression analysis techniques. The results showed that auditor competence and professional ethics have a negative and significant effect on auditors' dysfunctional behavior. Meanwhile, professional commitment has no effect on auditors' dysfunctional behavior.
\end{abstract}

Keywords: Auditor Competence, Professional Commitment, Professional Ethics, Dysfunctional Behavior

\begin{abstract}
Abstrak
Masalah penelitian terkait dengan perilaku disfungsional auditor dalam melakukan tugas audit. Tujuan penelitian untuk mengukur dan menganalisis pengaruh kompetensi auditor, komitmen profesional dan etika profesi terhadap perilaku disfungsional auditor pada Badan Pemeriksa Keuangan Perwakilan Propinsi Sulawesi Selatan. Metode pengumpulan data menggunakan teknik kuesioner dengan jumlah responden sebanyak 54 auditor. Analisis data menggunakan teknik analisis regresi berganda. Hasil penelitian menunjukan bahwa kompetensi auditor dan etika profesi berpengaruh negatif dan signifikan terhadap perilaku disfungsional auditor. Sedangkan komitmen profesional tidak berpengaruh terhadap perilaku disfungsional auditor.
\end{abstract}

Kata kunci: Kompetensi Auditor, Komitmen Profesional, Etika Profesi, Perilaku Disfungsional

* Corresponding author's e-mail: rahmanpura@stiem-bongaya.ac.id 


\section{PENDAHULUAN}

Pemerintah dituntun mengelola keuangan secara transparan dan akuntabel. Wujud dari akuntabilitas dan transparansi dalam pengelolaan keuangan terletak pada kualitas dalam menyajikan laporan keuangan. Karena laporan keuangan merupakan alat informasi keuangan sebagai dasar pertimbangan pihak-pihak yang berkepentingan dalam rangka mengambil keputusan. Agar laporan keuangan yang disajikan oleh pemerintah dapat berkualitas, maka peran auditor menjadi penting. Oleh karena itu, auditor yang bekerja pada Badan Pemeriksa Keuangan yang bertugas melakukan audit atas keandalan laporan keuangan yang disajikan oleh pemerintah harus mengedepankan prinsip-prinsip (Peraturan BPK RI No. 1 Tahun 2017 Tentang: Standar Pemeriksaan Keuangan Negara, n.d.). Dengan demikian, dalam melaksanakan penugasan audit, seorang auditor dilarang berperilaku disfungsional yakni perilaku penyimpangan dalam bentuk manipulasi,kecurangan terhadap standar audit yang telah ditetapkan. Menurut (Hartanto, 2016) perilaku audit disfungsional adalah setiap tindakan yang dilakukan auditor dalam pelaksanaan program audit yang dapat mereduksi atau menurunkan kualitas audit secara langsung maupun tidak. Namun dalam kenyataannya masih ada oknum auditor Badan Pemeriksa Keuagan yang masih melakukan kecurangan ketika melaksanakan tugas audit. Perilaku disfungsional auditor akan berdampak terhadap menurunnya kualitas hasil audit. Ada beberapa faktor yang berpengaruh terhadap disfungsional auditor yang akan diteliti adalah kompetensi auditor, komitmen professional dan etika profesi.

Auditor harus memiliki kompetensi profesional yang memadai dalam melaksanakan tugas audit (Peraturan BPK RI No. 1 Tahun 2017 Tentang: Standar Pemeriksaan Keuangan Negara, n.d.). Kompetensi auditor merupakan kemampuan yang dimiliki oleh auditor dalam melaksanakan tugas audit dapat berupa pengetahuan, keahlian dan keterampilan (Pura, 2017). Auditor yang memiliki kompetensi yang tinggi dapat mengontrol tindakan yang dilakukannya, sehingga prilaku kecurangan pada saat melaksanakan audit dapat ditekan (Martini \& Pertama, 2019). Dengan demikian semakin tinggi kompetensi auditor maka perilaku disfungsional auditor dapat ditekan.

Menurut (Fa'niansah et al., 2020) komitmen professional merupakan ciri khas yang melekat pada seseorang yang berkaitan dengan loyalitas atau kesetiannya pada tujuan dan nilai profesinya. Sehubungan dengan kegiatan audit maka yang dimaksud dengan komitmen professional adalah ciri khas yang melekat pada auditor yang menunjukkan kesetianya pada etika profesi. Menurut (Hartanto, 2016) seseorang memiliki komitmen terhadao profesinya diwujudkan dalam tiga karakteristik berikut ini : (1) suatu penerimaan atas tujuan-tujuan dan nilai-nilai profesi, (2) suatu kemauan untuk melakukan usaha sekuat tenaga demi kepentingan profesi, dan (3) suatu keinginan untuk memelihara dan mempertahankan keanggotaan dalam profesi. Dengan demikian auditot yang taat dan komitmen terhadap profesi tidak akan melakukan disfungsional pada saat melakukan audit

* Corresponding author's e-mail: rahmanpura@stiem-bongaya.ac.id 
Etika profesi merupakan faktor lain yang berpengaruh terhadap disfungsional auditor. Etika profesi merupakan suatu pedoman auditor professional dalam melaksanakan kegiatan audit. Seorang auditor sering diperhadapkan dengan situasi yang dilematis, sehingga etika profesi atau kode etik tersebut menjadi pedoman auditor dalam mengambil keputusan pada situasi yang sulit (Fa'niansah et al., 2020). Seorang auditor yang mengedepankan etika profesi dalam setiap pengambilan keputusan tentunya dia akan menahan diri dari godaan yang membuatnya melakukan perbuatan disfungsional.

\section{Rumusan Masalah}

Apakah kompetensi auditor, komitmen profesional dan etika profesi berpengaruh terhadap perilaku disfungsional auditor pada Badan Pemeriksa Keuangan (BPK) Perwakilan Sulawesi Selatan.

\section{Tujuan Penelitian}

Penelitian ini bertujuan untuk mengukur dan menguji pengaruh kompetensi auditor, komitmen profesional dan etika profesi terhadap perilaku disfungsional auditor pada Badan Pemeriksa Keuangan (BPK) Perwakilan Sulawesi Selatan.

\section{Kontribusi Penelitian}

Sebagai masukan kepada Badan Pemeriksa Keuangan (BPK) Perwakilan Sulawesi Selatan untuk meningkatkan kompetensi, komitmen dan etika anggota BPK sebagai upaya untuk memperbaiki perilaku dalam rangka meningkatkan kualitas audit.

\section{KERANGKA TEORITIS}

\section{Perilaku Disfungsional}

Pekerjaan akuntan pada dasarnya syarat dengan muatan moral yang dicermati di dalam kode etik profesi, pertimbangan moral menjadi faktor penting dalam semua aspek pekerjaan akuntan (Ludigdo, 2007). Aspek moral berkaitan dengan perlaku yang melekat pada diri auditor. Dalam melaksanakan audit, seorang auditor harus mengikuti prosedur audit, auditor tidak boleh mengambil keputusan menyimpang dari prosedur audit yang ditetapkan karena hal ini akan mempengaruhi menurunnya kualitas audit (Malahayati et al., 2019). Perilaku auditor dalam kegiatan audit yang menyimpang dari standar audit yang ditetapkan dan perilaku penyimpangan tersebut menyebabkan kualitas audit menjadi menurun disebut dengan perilaku disfungsional (Medina \& Challen, 2019). Perilaku disfungsional menyebabkan auditor menghasikan audit yang kurang berkualitas dan berimplikasi pada menurunnya kepercayaan masyarakat atau pengguna laporan keuangan terhadap profesi akuntansi. Menurut (Istiqomah \& Hanny, 2017) perilaku penyimpangan auditor pada dasarnya dilakukan dalam bentuk kecurangan terhadap standar audit sehingga berimplikasi pada menurunnya kualitas

* Corresponding author's e-mail: rahmanpura@stiem-bongaya.ac.id 206

http://openjournal.unpam.ac.id/index.php/JABI 
audit baik secara langsung maupun tidak langsung. Perilaku disfungsional auditor yang berpengaruh langsung terhadap menurunya kualitas audit dapat berupa premature sign off atau penghentian prosedur audit secara dini, pemerolehan bukti yang kurang, pemrosesan yang kurang akurat, dan kesalahan dari tahapan-tahapan audit. Sementara perilaku yang mempunyai pengaruh tidak langsung terhadap kualitas audit adalah underreporting of time yakni terjadi ketika auditor melaporkan waktu audit yang lebih singkat dari waktu aktual yang dipergunakan untuk menyelesaikan tugas audit tertentu. Perilaku underreporting of time dapat dilakukan melalui tindakan seperti; mengerjakan pekerjaan audit dengan menggunakan waktu personal (misalnya bekerja pada jam istirahat), mengalihkan waktu audit yang digunakan untuk pelaksanan tugas audit tertentu pada tugas lain yang pengerjaannya dilakukan pada waktu yang bersamaan, dan tidak melaporkan waktu lembur yang digunakan dalam mengerjakan prosedur atau tugas audit.

\section{Kompetensi Auditor}

Kompetensi auditor adalah kemampuan yang dimiliki seorang auditor berupa pengetahuan, keahlian dan keterampilan dalam melakukan kegiatan pemeriksaan yang dapat dikembangkan melalui proses pendidikan yang berkelanjutan. Berdasarkan (Peraturan BPK RI No. 1 Tahun 2017 Tentang: Standar Pemeriksaan Keuangan Negara, n.d.) menjelaskan bahwa pemeriksa secara kolektif harus memiliki kecakapan profesional yang memadai untuk melaksanakan tugas pemeriksaan. Kecakapan profesional pemeriksa dapat berupa pengetahuan, keahlian dan pengalaman yang dibutuhkan untuk melaksanakan tugas pemeriksaan. Untuk mempertahankan agar pemeriksa memiliki kompetensi yang memadai, maka kompetensi tersebut harus dipelihara atau dikembangkan melalui proses pendidikan profesional yang berkelanjutan. Pemeriksa yang ditugasi untuk melaksanakan pemeriksaan harus memiliki kompetensi/keahlian yang meliputi:

a. Pengetahuan tentang standar pemeriksaan, pengetahuan ini dapat diterapkan terhadap jenis pemeriksaan yang ditugaskan serta memiliki latar belakang pendidikan, keahlian dan pengalaman untuk menerapkan pengetahuan tersebut dalam pemeriksaan yang dilaksanakan.

b. Pengetahuan umum/objek pemeriksaan, pengetahuan ini tentang lingkungan entitas, program atau kegiatan yang diperiksa

c. Keterampilan berkomunikasi secara jelas dan efektif baik secara lisan maupun secara tulisan.

d. Keterampilan yang memadai untuk pemeriksaan yang dilaksankan, dapat berupa ; keterampilan dalam bidang statistik, teknologi informasi,

Auditor yang memiliki kompetensi yang baik, kemungkinan kecil dalam melakukan perilaku disfungsional audit (Martini \& Pertama, 2019).

* Corresponding author's e-mail: rahmanpura@stiem-bongaya.ac.id 


\section{Komitmen Profesional}

Menurut (Wahyuni, 2017) komitmen profesional merupakan sikap yang dimiliki oleh seorang individu yang ditandai dengan kesetiaanya terhadap suatu organisasi profesi di mana ia bekerja dan berikrar pada dirinya untuk mencapai tujuan dan keberhasilan organisasi karena dia adalah bagian dari organisai tersebut. Komitmen profesional dikembang kan dari komitmen organisasional. Selanjutnya Allen dan Meyer (1997) dalam (González \& Guillén, 2008) mengemukakan bahwa ada tiga kompenen komitmen yang harus dipahami oleh seseorang berhubungan dengan organisasi, yaitu :

a. Affective commitment, terjadi apabila karyawan ingin menjadi bagian dari organisasi karena adanya ikatan emosional terhadap organisasi.

b. Continuance commitment, terjadi apabila karyawan tetap bertahan pada suatu organisasi karena membutuhkan gaji dan keuntungan-keuntungan lain, atau karena karyawan tersebut tidak menemukan perkerjaan lain. Dengan kata lain karyawan tersebut tinggal diorganisasi itu karena ia membutuhkan organisasi tersebut.

c. Normative commitment, komitmen normatif timbul dari nilai-nilai diri karyawan. Karyawan bertahan menjadi anggota suatu organisasi karena memiliki kesadaran bahwa komitmen terhadap organisasi merupakan memang hal yang seharusnya dilakukan. Jadi, karyawan tersebut tinggal di organisasi itu karena dia merasa berkewajiban untuk itu.

Komitmen auditor terhadap profesinya merupakan faktor penting yang mempengaruhi perilaku auditor dalam melakukan audit. Auditor yang memiliki komitmen yang tinggi akan mampu menangani prilaku disfungsional auditor. Hasil penelitian (Fa'niansah et al., 2020), (Wahyuni, 2017) dan (Hartanto, 2016) menunjukan bahwa komitmen profesional berpengaruh positif terhadap perilaku disfungsinal auditor. Artinya semakin tinggi komitmen professional auditor, maka auditor semakin baik menangani perilaku disfungsional

\section{Etika Profesi}

Berdasarkan (Peraturan BPK RI No. 1 Tahun 2017 Tentang: Standar Pemeriksaan Keuangan Negara, n.d.) menjelaskan etika merupakab perilaku yang dimiliki oleh seseorang yang menunjukkan ketaatannya terhadap norma atau aturan yang berlaku pada suatu organisasi. Pekerjaan akuntan dikatakan sebagai suatu profesi jika harus mempunyai sikap dan perilaku etis (Agus \& Ardana, 2009). Sikap atau prilaku akuntan tercermin dalam kode etik akuntan. Prinsip kode etik profesional auditor terdiri dari; integritas, objektivitas, ketidakberpihakan, independen, mengutamakan kepentingan umum daripada kepentingan pribadi dan tidak melakukan perbuatan apapun yang merusak merusak reputasi profesi (Flint, 1988).

Lebih khusus dijelaskan dalam (Peraturan BPK RI No. 1 Tahun 2017 Tentang: Standar Pemeriksaan Keuangan Negara, n.d.) bahwa terdapat tiga prinsip etika yang

* Corresponding author's e-mail: rahmanpura@stiem-bongaya.ac.id 
merupakan nilai-nilai dasar yang dimiliki oleh anggota BPK atau pemeriksa dalam melakukan tugas audit, yaitu :

a. Independen

Suatu sikap dan tindakan dalam melaksanakan pemeriksaan untuk tidak memihak kepada siapapun dan tidak dipengaruhi oleh siapapun. Ada tiga dimensi independen yaitu independensi program, independensi investigasi dan indepedensi pelaporan (Mautz \& Sharaf, 1980)..

b. Integritas

Integritas merupakan mutu, sifat, atau keadaan yang menunjukkan kesatuan yang utuh, dimilikinya sifat jujur, kerja keras, serta kompetensi yang memadai.

c. Profesionalisme

Profesionalisme merupakan kemampuan, keahlian, dan komitmen profesi dalam menjalankan tugas disertai prinsip kehati-hatian (due care), ketelitian, dan kecermatan, serta berpedoman kepada standar dan ketentuan peraturan perundang-undangan.

Etika profesi merupakan suatu hal yang penting untuk auditor dalam melakukan praktik audit. Auditor dengan etika profesi yang tinggi cenderung tidak tidak terlibat dalam perilaku disfungsional audit. Hasil peneitian (Fa'niansah et al., 2020) dan (Chasbiandani et al., 2019) menjukkan bahwa etika profesi berpengaruh signifikan terhadap perlaku disfungsional auditor.

\section{METODE RISET}

Penelitian ini merupakan penelitian dengan pendekatan kuantitatif yakni penelitian yang dimulai dengan pengembangan proposisi dan hipotesis kemudian hipotesis tersebut diuji dengan data secara kuantitatif hingga menemukan sebuah konsep/tesa baru atau hipotesis yang teruji (Ferdinand, 2011). Populasi penelitian adalah auditor yang bekerja pada Badan Pemeriksa Keuangan Perwakilan Propinsi Sulawesi Selatan. Penarikan sampel menggunakan teknik Simple Random Sampling (Sugiyono, 2016). Metode pengumpulan data menggunakan teknik kuesioner (Sekaran \& Bougie, 2017). Jumlah sampel sebanyak 54 auditor.

Variabel penelitian terdiri dari perilaku disfungsional auditor (Y) sebagai variabel independe, kemudian independen terdiri dari kompetensi auditor (X1), komitmen professional (X2) dan etika profesi (X3). Variabel tersebut diukur dengan indikator sebagai berikut:

Tabel 1 : Operasional Variabel

\begin{tabular}{|c|l|l|l|}
\hline No & \multicolumn{1}{|c|}{ Variabel } & \multicolumn{1}{|c|}{ Indiktor } & \multicolumn{1}{|c|}{$\begin{array}{c}\text { Skala } \\
\text { Pengukuran }\end{array}$} \\
\hline 1 & $\begin{array}{l}\text { Perilaku Disfungsional } \\
\text { Auditor (Y) }\end{array}$ & $\begin{array}{l}\text { 1. Premature sign off } \\
\text { 2. Underreporting of time }\end{array}$ & Ordinal \\
\hline
\end{tabular}

* Corresponding author's e-mail: rahmanpura@stiem-bongaya.ac.id 


\begin{tabular}{|c|c|c|c|}
\hline & & Sumber : (Istiqomah \& Hanny, 2017) & \\
\hline 2 & $\begin{array}{ll}\text { Kompetensi } & \text { Auditor } \\
\left(\mathrm{X}_{1}\right) & \end{array}$ & $\begin{array}{l}\text { 1. Pengetahuan tentang standar pemeriksaan } \\
\text { 2. Pengetahuan umum/objek pemeriksaan } \\
\text { 3. Keterampilan berkomunikasi } \\
\text { 4. Keterampilan yang memadai untuk } \\
\text { pemeriksaan yang dilaksankan } \\
\text { Sumber: (Peraturan BPK RI No. } 1 \text { Tahun } 2017 \\
\text { Tentang: Standar Pemeriksaan Keuangan } \\
\text { Negara, n.d.) }\end{array}$ & Ordinal \\
\hline 3 & $\begin{array}{l}\text { Komitmen Profesional } \\
\left(\mathrm{X}_{2}\right)\end{array}$ & $\begin{array}{l}\text { 1. Affective commitment } \\
\text { 2. Continuance commitment } \\
\text { 3. Normative commitment } \\
\text { Sumber : (González \& Guillén, 2008) }\end{array}$ & Ordinal \\
\hline 4 & Etika Profesi $\left(\mathrm{X}_{3}\right)$ & $\begin{array}{l}\text { 1. Independen } \\
\text { 2. Integritas } \\
\text { 3. Professionalisme } \\
\text { Sumber: (Peraturan BPK RI No. } 1 \text { Tahun } 2017 \\
\text { Tentang: Standar Pemeriksaan Keuangan } \\
\text { Negara, n.d.) }\end{array}$ & Ordinal \\
\hline
\end{tabular}

Untuk melakukan analisis data menggunakan analisis regresi berganda, dengan persamaan regresi sebagai berikut :

$$
\mathrm{Y}=\alpha+\beta_{1} \mathrm{X}_{1}+\beta_{2} \mathrm{X}_{2}+\beta_{3} \mathrm{X}_{3}+\mathrm{e}
$$

$\begin{array}{ccl}\text { Keterangan: } & \\ \mathrm{Y} & : & \text { Perilaku disfungsional auditor } \\ \alpha & : & \text { Konstanta } \\ \beta_{1-3} & : & \text { Koefisien regresi } \\ \mathrm{X}_{1} & : & \text { Kompetensi auditor } \\ \mathrm{X}_{2} & : & \text { Komitmen profesional } \\ \mathrm{X}_{3} & : & \text { Etika profesi }\end{array}$

\section{ANALISIS DAN PEMBAHASAN}

\section{Hasil Uji Validitas dan Reliabilitas}

Hasil penelitian yang valid bila terdapat kesamaan antara data yang terkumpul dengan data yang sesungguhnya terjadi pada objek yang diteliti, sedangkan hasil penelitian yang reliabel bila terdapat kesamaan data dalam waktu yang berbeda (Sugiyono, 2016)

Uji validasi data dalam penelitian ini dilakukan dengan teknis analisis item, yaitu dengan cara mengkorelasikan skor tiap-tiap item pertanyaan dengan total skor untuk masing-masing variabel. teknik korelasi yang digunakan dalam melakukan uji validasi adalah Pearson Product Moment (Riduwan, 2008). Kriteria yang digunakan untuk menyatakan suatu instrumen dianggap valid atau layak digunakan dalam pengujian hipotesis apabila koefisien korelasi lebih besar atau sama dengan 0,30 . Hasil uji validitas data dapat dilihat dari tabel berikut ini :

* Corresponding author's e-mail: rahmanpura@stiem-bongaya.ac.id 
Tabel 2 : Hasil Uji Validitas Data

\begin{tabular}{lcccccc}
\hline \multirow{2}{*}{ Variabel } & \multicolumn{5}{c}{ Nilai r Hitung Untuk Setiap Item Pertanyaan } \\
\cline { 2 - 7 } & No.1 & No.2 & No.3 & No.4 & No.5 & No.6 \\
\hline Kompetensi Auditor $X_{1}$ & 0,62 & 0,56 & 0,68 & 0,63 & 0,62 & 0,67 \\
Komite Profesional X & 0,68 & 0,58 & 0,40 & 0,51 & 0,47 & 0,71 \\
Etika Profesi X & 0,62 & 0,72 & 0,66 & 0,63 & 0,58 & 0,76 \\
Perilaku disfungsional & 0,68 & 0,82 & 0,71 & 0,76 & 0,64 & 0,67 \\
auditor Y & & & & & & \\
\hline r Kritis & 0,30 & 0,30 & 0,30 & 0,30 & 0,30 & 0,30 \\
\hline Keputusan & Valid & Valid & Valid & Valid & Valid & Valid \\
\hline Sumber data
\end{tabular}

Sumber data : Hasil olahan tahun 2020

Berdasarkan data tersebut menunjukkan bahwa semua item pertanyaan dari semua variabel penelitian memiliki nilai korelasi ( $\mathrm{r}$ hitung) lebih besar dari nilai $\mathrm{r}$ kritis $(0,30)$. Dengan demikian semua item pertanyaan dikatakan valid. Artinya bahwa terdapat kesamaan data yang terkumpul dengan data yang sesungguhnya.

Kemudian uji reliabilitas pada penelitian ini dilakukan dengan menggunakan metode Alpha. Kriteria yang digunakan untuk menyatakan suatu instrumen dikatakan reliabel jika memberikan nilai Cronbach Alpha $(\alpha)$ lebih besar daripada 0,60 (Nunnally, 1967) dalam dalam (Ghozali, 2005). Hasil perhitungan Reliabilitas data dapat dilihat dalam tabel berikut ini:

Tabel 3 : Hasil Uji Reliabilitas Data

\begin{tabular}{lccl}
\hline \multicolumn{1}{c}{ Variabel } & Nilai Alpha & Nilai Kritis & Keputusan \\
\hline Kompetensi Auditor $\mathrm{X}_{1}$ & 0,71 & 0,60 & Reliabel \\
Komite Profesional $\mathrm{X}_{2}$ & 0,72 & 0,60 & Reliabel \\
Etika Profesi X & 0,74 & 0,60 & Reliabel \\
Perilaku disfungsional auditor Y & 0,81 & 0,60 & Reliabel
\end{tabular}

Sumber data : Hasil olahan tahun 2020

Berdasarkan hasil pengujian tersebut menunjukkan bahwa nilai alpha dari setiap variabel lebih besar dari nilai kritis $(0,60)$ sehingga data ini dikatakan reliabel. Dalam artian bahwa terdapat kesamaan data dalam waktu yang berbeda.

\section{Hasil Uji Asumsi Klasik}

Suatu penelitian dengan menggunakan analisis regresi harus memenuhi syarat uji asumsi klasik, oleh karena ini sebelum data dianalisis dengan regresi data tersebut diuji terlebih dahulu melalui uji asumsi klasik. Adapun hasil pengujian asumsi klasik dalam penelitian ini adalah sebagai berikut:

* Corresponding author's e-mail: rahmanpura@stiem-bongaya.ac.id 


\section{Uji Normalitas}

Data yang akan dianalisis dengan menggunakan analisis regresi harus berdistribusi normal, pengujian normalitas data dalam penelitian ini menggunakan analisis statistik, yaitu dengan menggunakan uji Kolmogorov-Smirnov (KS). Hasil uji normalitas dengan menggunakan uji KS dapat dilihat dari tabel berikut ini:

\section{Tabel 4 Uji Normalitas}

\begin{tabular}{lc}
\hline & Unstandardized Predicted \\
& Value \\
\hline $\mathrm{N}$ & 56 \\
Test Statistic & 0,087 \\
Asymp. Sig. (2-tailed) & 0,200 \\
\hline Sumber : Data diolah menggunakan SPSS 24 (2020) &
\end{tabular}

Berdasarkan tabel di atas menunjukkan nilai signifikasi yaitu sebesar 0,200. Nilai signifikasi tersebut lebih besar dari nilai 0,050 yang dapat dikatakan bahwa data yang digunakan dalam penelitian ini berdistribusi normal, sehingga asumsi untuk pengujian normalitas data terpenuhi dan analisis data dapat dilanjutkan

\section{Uji Multikolinearitas}

Asumsi multikolinearitas adalah asumsi yang menggambar tidak ada hubungan kolinearitas antara variabel independen yang diteliti. Untuk menguji multikolinearitas menggunakan analisis Tolerance dan VIF. Hasil ujinya dapat dilihat dalam tabel berikut ini :

Tabel 5 Uji Multikolinearitas

\begin{tabular}{llc}
\hline \multicolumn{1}{c}{ Model } & \multicolumn{2}{c}{ Collinearitas Statistic } \\
& Tolerance & VIF \\
\hline Kompetensi Auditor $\mathrm{X}_{1}$ & 0,554 & 1,806 \\
Komite Profesional $\mathrm{X}_{2}$ & 0,650 & 1,538 \\
Etika Profesi $\mathrm{X}_{3}$ & 0,775 & 1,291 \\
\hline
\end{tabular}

Sumber : Data diolah menggunakan SPSS 24 (2020)

Berdasarkan table di atas menunjukkan nilai tolerance dan nilai VIF pada masing-masing variable. Nilai tolerance pada masing-masing variabel tersebut lebih besar dari nilai 0,10 dan nilai VIF pada masing-masing variable lebih kecil dari nilai 10,0 yang dapat dikatakan bahwa tidak terdapat masalah. Artinya tidak hubungan antara kolinearitas antara variabel independen yang diteliti sehingga asumsi kolinieritas dalam penelitian ini terpenuhi.

\section{Hasil Uji Analisis Determinasi $\left(R^{2}\right)$}

Analilis determinasi digunakan untuk mengetahui berapa besar variasi perubahan variabel independen terhadap variabel dependen. Dengan kata lain untuk mengukur berapa besar konstribusi variabel independen dalam mempengaruhi variabel dependen. Untuk mengukur besarnya kontribusi pengaruh variabel Kompetensi Auditor, Komitmen Profesional

* Corresponding author's e-mail: rahmanpura@stiem-bongaya.ac.id 
dan Etika Profesi terhadap perilaku disfungsional auditor dapat lihat dari nilai $R$ Square, seperti terlihat dari tabel berukut ini:

Tabel 6 Analisis Determinasi

\begin{tabular}{cccc}
\hline Model & $\mathrm{R}$ & $\begin{array}{c}\mathrm{R} \\
\text { Square }\end{array}$ & Adjusted R Square \\
\hline Sumber & 0,549 & 0,302 & 0,261 \\
\hline Pata diolah menggunakan & SPSS 24 (2020)
\end{tabular}

Berdasarkan data pada tabel di atas menunjukkan nilai $\mathrm{R}$ square yaitu sebesar 0,302. Hal ini berarti bahwa variabel Kompetensi Auditor, Komitmen Profesional dan Etika Profesi secara bersama-sama mempengaruhi variabel perilaku disfungsional auditor sebesar $26,1 \%$. Sedangkan sebesar 73,9\% (100\% - 26,1\%) dipengaruhi oleh variabel lain yang tidak dimasukkan dalam penelitian ini. Dengan kata lain kontribusi kompetensi auditor, komitmen profesional dan etika profesi mempengaruhi variabel perilaku disfungsional auditor sebesar $26,1 \%$.

\section{Hasil Uji Koefisien Regreasi dan Persamaan Regresi}

Nilai koefisien regresi pengaruh kompetensi auditor, komitmen profesional dan etika profesi terhadap perilaku disfungsional auditor dapat dilihat pada tabel koefisien berikut ini :

Tabel 7 Hasil Perhitungan Koefisien Regresi

\begin{tabular}{lrrrr}
\hline \multicolumn{1}{c}{ Uraian } & Koefisien regresi & Standar Error & t hitung & probabiliy \\
\hline Konstanta & 43,553 & 4,874 & 8,936 & 0,000 \\
Kompetensi Auditor $\mathrm{X}_{1}$ & $-0,333$ & 0,163 & $-2,041$ & 0,046 \\
Komite Profesional $\mathrm{X}_{2}$ & $-0,057$ & 0,221 & $-0,259$ & 0,796 \\
Etika Profesi $\mathrm{X}_{3}$ & $-0,319$ & 0,141 & $-2,263$ & 0,028 \\
\hline
\end{tabular}

Sumber : Data diolah menggunakan SPSS 24 (2020)

Berdasarkan data tersebut maka persamaan regresinya adalah :

$$
Y=43,553-0,333 X_{1}-0,057 X_{2}-0,319 X_{3}
$$

Model tersebut menjelaskan nilai koefisien variabel Kompetensi Auditor bertanda negatif sebesar $-0,333$ berarti apabila Kompetensi Auditor meningkat 1 point, maka perilaku Disfungsional Auditor akan menurun $0,33 \%$ pada saat variabel independen lainnya tidak berubah, variabel Komite Professional memiliki koefisien regresi bertanda negative 0,057 yang berarti apabila Komite Professional meningkat 1 point maka Perilaku Disfungsional Auditor menurun sebesar $0,057 \%$ pada saat variabel independen lainnya tidak berubah, variabel Etika Profesi memiliki koefisien regresi bertanda negatif 0,319 berarti apabila Etika Profesi meningkat 1 point, maka perilaku disfungsional auditor menurun sebesar $0,319 \%$ pada saat

* Corresponding author's e-mail: rahmanpura@stiem-bongaya.ac.id 
variabel bebas lainnya tidak berubah. Dan jika Kompetensi Auditor, Komite Profesional dan Etika Profesi tidak mengalami perubahan maka Perilaku Disfungsional Auditor memiliki nilai $43,55 \%$.

\section{Pembahasan}

\section{Pengaruh Kompetensi Auditor terhadap Perilaku Disfungsional Auditor}

Untuk mengetahui apakah Kompetensi Auditor berpengaruh terhadap perilaku disfungsional auditor pada BPK RI Perwakilan Sulawesi Selatan dapat dilihat dari hasil analisis data. Berdasarkan analisis koefisien regresi menunjukkan variabel Kompetensi Auditor memiliki koefisien regresi bertanda negatif sebesar 0,333. Nilai probabilitas sebesar 0,046 lebih kecil dari 0,05. Hasil analisis ini menunjukkan Kompetensi Auditor berpengaruh negatif dan signifikan terhadap perilaku disfungsional auditor. Semakin tinggi Kompetensi Auditor maka semakin kecil perilaku disfungsional auditor. Auditor yang memiliki kompetensi yang baik cenderung tidak melakukan perbuatan disfungsional dalam melakukan kegiatan audit. Hasil penelitian ini sesuai hasil penelitian yang dilakukan oleh (Martini \& Pertama, 2019) bahwa Komite Audit berpengaruh negatif signifikan terhadap perilaku disfungsional auditor. Kemampuan seorang auditor dalam melakukan kegiatan audit merupakan unsur yang penting. Sehingga dalam (Peraturan BPK RI No. 1 Tahun 2017 Tentang : Standar Pemeriksaan Keuangan Negara, n.d.) menegaskan pemeriksa di dalam melakukan kegiatan audit harus memiliki kemampuan profesional yang dibuktikan dengan sertifikat kompetensi dari lembaga yang berwewenang.

\section{Pengaruh Komitmen Profesional Terhadap Perilaku Disfungsional Auditor}

Kemudian komitmen profesional berpengaruh terhadap perilaku disfungsional dapat dari hasil analisis data menunjukan bahwa nilai koefisien variabel komitmen profesional bertanda negatif sebesar 0,057. Nilai probabilitas sebesar 0,796, nilai ini lebih besar dari 0,05, artinya tidak signifikan. Hasil analisis ini menunjukkan bahwa komitmen profesional berpengaruh negatif tidak signifikan terhadap perilaku disfungsional auditor. Dalam artian bahwa komitmen profesional tidak berpengaruh terhadap perilaku disfungsional. Dengan demikian auditor yang komitmen terhadap Kantor Akuntan Publik tidak menjadi faktor bahwa seorang auditor berperilaku disfungsional atau tidak. Komitmen profesional sebagai suatu sikap yang lahir dari diri auditor yang sifatnya kondisional, sehingga pada saat seorang auditor memiliki komitmen yang tinggi terhadap profesinya maka tidak berbuat prilaku disfungsional, sebaliknya ketika auditor yang memiliki komitmen profesional rendah kecenderungan bisa melakukan perbuatan disfungsional. Penelitian ini mendukung penelitian yang dilakukan oleh (Istiqomah \& Hanny, 2017).

* Corresponding author's e-mail: rahmanpura@stiem-bongaya.ac.id 


\section{Pengaruh Etika Profesi Terhadap Perilaku Disfungsional Auditor}

Hasil analisis data menunjukkan bahwa etika profesi berpengaruh negatif dan signifikan terhadap perilaku disfungsional auditor. Hal ini dilihat nilai koefisien regresi variabel etika profesi bertanda negatif sebesar 0,319. Dan nilai probability sebesar 0,028 lebih kecil dari 0,05 yang artinya berpengaruh signifikan. Hasil penelitian ini bermakna semakin tinggi Etika Profesi maka kecil keinginannya untuk melakukan Perilaku Disfungsional Auditor. Etika profesi merupakan unsur penting dalam kegiatan audit, sehingga apabila seorang auditor memahami etika profesi maka dalam melakukan kegiatan audit selalu patuh terhadap kode etik dan tidak akan berperilaku disfungsional dalam melakukan audit (Mahardini et al., 2014). Kepatuhan terhadap kode etik menjadi keharusan bagi auditor BPK dalam menjalankan tugas audit (Peraturan BPK RI No. 1 Tahun 2017 Tentang: Standar Pemeriksaan Keuangan Negara, n.d.). Hasil penelitian ini sejalan dengan penelitian yang dilakukan oleh (Fa'niansah et al., 2020), (Chasbiandani et al., 2019) (Oktaviani et al., 2016) dan (Mahardini et al., 2014)

\section{KESIMPULAN DAN SARAN}

Kesimpulan pada penelitian ini adalah Komite Audit berpengaruh negatif dan signfikan terhadap Perilaku Disfungsional Auditor, Komitmen Profesional tidak berpengaruh terhadap Perilaku Disfungsional Auditor dan Etika Profesi berpengaruh negatif dan signifikan terhadap Perilaku Disfungsional Auditor

Saran yang diberikan oleh peneliti adalah agar Badan Pemeriksa Keuangan (BPK) Perwakilan Sulawesi Selatan agar selalu meningkatkan kompetensi, komitmen dan etika anggota BPK sebagai upaya untuk memperbaiki perilaku dalam rangka meningkatkan kualitas audit. Dan untuk penelitian selanjutnya diharapkan menambah objek penelitian agar lebih luas penelitian mengenai Perilaku Disfungsional Auditor.

\section{DAFTAR PUSTAKA}

Agus, S., \& Ardana, I. C. (2009). Etika Bisnis dan Profesi : Tantangan Membangun Manusia Seutuhnya. Salemba Empat.

Chasbiandani, T., Satra, I., \& Rizal, N. (2019). Sifat Machiavellian Dan Etika Profesi Dalam Perilaku. Jurnal Ekonomi : Journal of Economic, 10(2), 150-160.

Fa'niansah, N., Mursalim, \& Amiruddin. (2020). Pengaruh Locus of Control, Job Performance, Komitmen Profesionalisme, Time Budged Pressure, Etika Profesi Terhadap Perilaku Disfungsional Auditor. Jurnal Ilmu Ekonomi, 3(3), 43-56.

* Corresponding author's e-mail: rahmanpura@stiem-bongaya.ac.id 
Ferdinand, A. (2011). Metode Penelitian Manajemen. Badan Penerbit Universitas Diponegoro.

Flint, D. (1988). Philosophy and Principles of Auditing. Macmilan Education Ltd.

Ghozali, I. (2005). Aplikasi Analisis Multivariate Dengan Program SPSS. BP Universitas Diponegoro.

González, T. F., \& Guillén, M. (2008). Organizational commitment: A proposal for a wider ethical conceptualization of "normative commitment." Journal of Business Ethics, 78(3), 401-414. https://doi.org/10.1007/s10551-006-9333-9

Hartanto, O. (2016). Pengaruh Locus of Control, Tekanan Anggaran Waktu Komitmen Profesional, Terhadap Perilaku Disfungsional Auditor. EKUITAS (Jurnal Ekonomi Dan Keuangan), $20(4), \quad 473$. https://doi.org/10.24034/j25485024.y2016.v20.i4.1826

Istiqomah, S. F., \& Hanny, R. (2017). Studi Empiris Faktor-Faktor Yang Memengaruhi Perilaku Disfungsional Audit. Jurnal Akuntansi, 21(2), 184-207. https://doi.org/10.24912/ja.v21i2.194

Ludigdo, U. (2007). Paradoks Etika Akuntan. Pustaka Pelajar.

Mahardini, N. M., Sujana, E., \& Adiputra, M. P. (2014). Pengaruh Etika Profesi dan Tekanan Anggaran Waktu Terhadap Perilaku Disfungsional Auditor (Studi Kasus pada Kantor Akuntan Publik di Provinsi Bali). E-Journal S1 Akutansi Universitas Pendidikan Ganesha, 2(1), 1-11.

Malahayati, B. A., Maslichah, \& Mawardi, M. C. (2019). Pengaruh Profesionalisme dan Perilaku Disfungsional Auditor Pada Kualitas Audit dengan Kepuasan Kerja Sebagai Variabel Moderasi. E-JRA, 08(05), 31-43.

Martini, N. P. R., \& Pertama, I. G. A. W. (2019). Perilaku Disfungsional Auditor: Dampak Komite Audit, Sifat Machiavellian, Tekanan Waktu Dan Tekanan Ketaatan (Studi Kasus KAP di Bali). Wacana Ekonomi (Jurnal Ekonomi, Bisnis Dan Akuntansi), 18(1), 66-74. https://ejournal.warmadewa.ac.id/index.php/wacana_ekonomi

Mautz, R. K., \& Sharaf, H. A. (1980). The Philosophy Of Auditing. American Accounting Association.

Medina, L. E., \& Challen, A. E. (2019). Locus Of Control, Turnover Intention, Kinerja Auditor, Etika Auditor, Komitmen Organisasi Dan Dysfunctional Audit Behavior. Jurnal Pajak, Akuntansi, Sistem Informasi, Dan Auditing, 1(1), 1-21.

Oktaviani, W., Hardi, \& Silfi, A. (2016). Pengaruh Personalitas Auditor dan Etika Profesi Terhadap Penerimaan Perilaku Audit Disfungsional (Studi Empiris Bpk RI Perwakilan Provinsi Riau). JOMFekom, 4(1), 843-857.

* Corresponding author's e-mail: rahmanpura@stiem-bongaya.ac.id 216

http://openjournal.unpam.ac.id/index.php/JABI 
https://media.neliti.com/media/publications/125589-ID-analisis-dampakpemekaran-daerah-ditinja.pdf

Peraturan BPK RI No. 1 Tahun 2017 Tentang: Standar Pemeriksaan Keuangan Negara.

Pura, R. (2017). Effects of Auditor Competence, Information Technology, Accounting Information Systems and Organizational Commitment on Auditors' Performance at The State Audit Agency, In South Sulawesi. Scientific Research Journal, V(X), $16-22$.

Riduwan. (2008). Metode dan Teknik Menyusun Tesis. Alfabeta.

Sekaran, U., \& Bougie, R. (2017). Metode Penelitian untuk Bisnis. Salemba Empat.

Sugiyono. (2016). Metode Penelitian Manajemen (Bandung). Alfabeta.

Wahyuni, S. (2017). Pengaruh Komitmen Profesional Multi Dimensi Terhadap Perilaku Underreporting of Time ( Studi Empiris Pada Kantor Akuntan Publik Second Tiers Di Indonesia ). 14(2).

* Corresponding author's e-mail: rahmanpura@stiem-bongaya.ac.id 